\author{
(1) Mehmet Turan İnal, \\ (D) Dilek Memiş, \\ (D) Emin Tunç Demir, \\ (D) Ahmet Șenol Uyar, \\ (D) İsmail Arslan, \\ (D) Poyraz Bozkurtlu
}

\section{Simplified Weaning After Use of Quetiapine in a Patient: Case Report}

\author{
Ketiapin Kullanımı Sonrası Kolaylaşmış Weaning: Olgu \\ Sunumu
}

Received/Geliş Tarihi : 23.12.2019

Accepted/Kabul Tarihi : 20.02.2020

${ }^{(C)}$ Copyright 2020 by Turkish Society of Intensive Care Turkish Journal of Intensive Care published by Galenos Publishing House.
Mehmet Turan Inal, Dilek Memiş, Emin Tunç Demir, Ahmet Şenol Uyar, Ismail Arslan, Poyraz Bozkurtlu Trakya University Faculty of Medicine, Department of Anesthesiology and Reanimation, Division of Intensive Care, Edirne, Turkey

Mehmet Turan Inal MD (函,

Trakya University Faculty of Medicine, Department of Anesthesiology and Reanimation, Division of Intensive Care, Edirne, Turkey

E-mail : mehmetturaninal@yahoo.com

Phone : : +905324301944

ORCID ID : orcid.org/0000-0001-8462-4299

\begin{abstract}
Delirium is an organic dysfunction including the brain's inflammatory response to injury, hormonal effects and changes in neurotransmission and neural network. Delirium is one of the major causes of weaning difficulty in intensive care unit (ICU) patients. In this case report, we tried to explain the successful weaning procedure in a patient using quetiapine after trying all treatment options due to delirium in the ICU. This report emphasizes that second-generation antipsychotics should be kept in mind in patients who cannot be disconnected from the mechanical ventilator due to delirium.
\end{abstract}

Keywords: Quetiapine, weaning, delirium

ÖZ Deliryum, beynin yaralanmalara, hormonal etkilere ve nörotransmisyon ve sinir ağındaki değişikliklere karşı enflamatuvar yanıtı içeren organik bir işlev bozukluğudur. Deliryum yoğun bakım ünitesi (YBÜ) hastalarında weaning zorluğunun en önemli nedenlerinden biridir. Bu olgu sunumunda, YBÜ'deki deliryuma bağı tüm tedavi seçeneklerini denedikten sonra ketiapin kullanan bir hastada başarıı weaning prosedürünü açıklamaya çalıştık. Bu rapor, deliryum nedeniyle mekanik ventilatörle bağlantısı kesilemeyen hastalarda ikinci kuşak antipsikotiklerin akılda tutulması gerektiğini vurgulamaktadır.

Anahtar Kelimeler: Ketiapin, weaning, deliryum

\section{Introduction}

Weaning is a major component in the treatment of intensive care patients. The definition of weaning is a gradual reduction of support for mechanical ventilation. Liberation of the patients from mechanical ventilation constituted an important workload in intensive care and constitutes 40-50\% of all workload in intensive care unit (ICU) $(1,2)$.

Delirium is one of the major causes of weaning difficulty in ICU patients. Delirium is an organic dysfunction including the brain's inflammatory response to injury, hormonal effects and changes in neurotransmission and neural network $(3,4)$. Several studies have shown that delirium is associated with increased mortality, unsuccessful weaning process, prolonged mechanical ventilation, ICU and length of hospital stay in critically ill patients $(5,6)$. As a result, due to prolonged mechanical ventilator therapy, ventilator associated pneumonia and ventilator related lung injuries were reported (7).

The evidence on the use of psychotropic drugs during weaning are limited in delirium patients. Quetiapine is a second-generation antipsychotic agent and effective on multiple neurotransmitter receptors including serotonin 5-HT1 A and 5-HT2, dopamine D1 and D2, histamine H1, and adrenergic 1 and 2 receptors (8).

In this case report, we aimed to explain the successful weaning process after quetiapine use in a trauma patient who could not be separated from the mechanical ventilator due to fear of not breathing. 


\section{Case Report}

A 33-year-old $70 \mathrm{~kg}$ female patient was admitted to the emergency department after a road accident. The patient who was found to have laceration in the liver was taken immediately and taken to the ICU after the operation. During operation $3000 \mathrm{~mL}$ crystalloid, seven units of red blood cells, nine units of fresh frosen plasma, six unit cryoprecipitate and two units of platelet suspension were given to the patient due to the bleeding. The patient had $2000 \mathrm{~mL}$ bleeding during the operation.

After the patient was admitted to the ICU, due to the bleeding from abdominal drens, the presence of infiltrates and insufficient respiration she had to be mechanical ventilation. Dextmetedomidin and fentanyl infusion was started. Emergency abdominal tomography and ultrasound were reported as normal.

Ventilation was continued for ten days, because the patient developed other complications such as pneumoniae and sepsis. Because of these diagnoses, and failure to comply with mechanical ventilator, the patient was administered infusions of dextmedetomidine and propofol for sedation, fentanyl and morphine intravenously for analgesia in repeated periods. During this period the sedation and analgesia infusions stopped every day but uncontrollable behaviors, hypoxia and fears were seen in the patient. To control these symptoms sedation and analgesic infusions continued. Results of electrolyte tests, arterial blood gases and vital signs were all within normal limits. The intensive care delirium screening test (ICDSC) was done to patient every day and the ICDSC test was found 5 . We also used earplug, music and lighting off in this patient for preventing anxiety. The patient did not describe a psychological illness in her history. Due to the severe agitation haloperidol $4 \mathrm{mg}$ per oral was added to her chart. At this time, the patient was attempted to disconnect from the mechanical ventilator, but was afraid of not breathing, and did not want to leave the mechanical ventilator. Although the patient was barely separated from the mechanical ventilator several times and no abnormal values of tachycardia, tachypnea, and peripheral oxygen saturation were detected, she re-administered with mechanical ventilator by the intense demands and coercion.

Although a decrease was detected in the patient's anxiety after haloperidol administration, the patient still very agitated and so haloperidol administration was stopped and quetiapine $50 \mathrm{mg}$ in the morning $50 \mathrm{mg}$ in the afternoon and $100 \mathrm{mg}$ at night was started. On the same day her nurse was reported low anxiety of the patient, and stopped infusions for sedation and analgesia. On the following day the patient was extubated, she discharged from intensive care with normal hemodynamics and chest radiography on the next day.

\section{Discussion}

In this case report, we tried to explain the successful weaning procedure in a patient using quetiapine after trying all treatment options due to delirium in the ICU after patient consent is obtained.

The weaning process is simple for about $70 \%$ of patients and the remaining 30\% fails, makes it difficult to weaning and worsens the prognosis (9). In order to separate the patient from the mechanical ventilator, the pathology should be regressed, the consciousness should be clear, the breathing is normal, there is no cardiac problem, the metabolic and hemodynamic status should be stable, malnutrition and psychological status should be stable (10). In our patient we have ruled out pathologies such as lung pathologies, insomnia, unconsciousness, etc, which can lead to weaning difficulties and we thought that the only reason leading to weaning difficulties could be anxiety and delirium. Panic attack and acute stress disorder should be considered in the differential diagnosis of anxiety in this patient. Panic attacks can be observed with different clinical findings such as fear of crushing, feeling of loss of control and difficulty in breathing, physical hypersensitivity such as sweating and tremor. Panic attacks are typically short-lived and are initially dense within 10 minutes. Our patient did not have a spontaneous panic attacks and although anxiety gradually intensified, it was never care free. Acute stress disorder is manifested with dissociative amnesia, depersonalization, derealization and desensitization 2 to 4 weeks after a general life-threatening stress (11). In this patient we don't observed amnesia, depersonalization, derealization or desensitization. In this case delirium should be considered. We detected delirium by using ICDSC test every day, and the ICDSC test was found as 5 .

Delirium is frequently reported to be due to a balance disorder between cholinergic and dopaminergic neurotransmitter systems (12). Acetylcholine and serotonin neurotransmitters have main roles in the development of delirium (13).

Each critical care patient should be kept away from the risk factors associated with delirium and the patient should 
be treated if delirium develops. In a recent review, the risk factors for delirium in adults include benzodiazepine use, blood transfusions, advanced age, dementia, coma status, emergency surgery or trauma, and high Acute Physiologic Assessment and Chronic Health Evaluation and the American Society of Anesthesiologists scores (14). In our patient, trauma, multipl blood transfusions and emergency surgery were risk factors for delirium. The same guideline (14) recommended music, massage, providing sleep pattern, avoiding from noise and light to relieve patients from delirium. In a case report (8), the authors firstly used these relaxation methods for a patient who can not weaned from the mechanical ventilator, but the patient could not adapt to relaxation methods due to anxiety. We also used earplug, music and lighting off for preventing anxiety and delirium in our patient.

The most commonly used agents for treating delirium were haloperidol, olanzapine, quetipine, risperidone and ziprasidone $(15,16)$. Quetiapine is a second-generation antipsychotic agent and effective on multiple neurotransmitter receptors including serotonin 5-HT1A and 5-HT2, dopamine $\mathrm{D} 1$ and $\mathrm{D} 2$, histamine $\mathrm{H} 1$, and adrenergic 1 and 2 receptors (8). Quetiapine may be associated with patients who receive only intravenous haloperidol therapy, with a more favorable tendency in the case of faster resolution of the delirium, shorter agitation time, and discharge in hospital (17). Rosenthal et al. (8) reported a patient that can't weaned from the mechanical ventilator due to the anxiety state, after that they started to used quetiapine for the patient and they have been successful in weaning period, and Seemüller et al. (18) also described a successful weaning after using quetiapine in a patient who stayed in ICU for a long time after esophageal rupture. In an another study made by Devlin et al. (17), the authors reported that quetiapine added to haloperidol is relative to faster delirium resolution and less agitation. They used quetiapine $50 \mathrm{mg}$ every 12 hours, increased the dose to the $200 \mathrm{mg}$ in every 12 hours. In another study Kim et al. (19) the authors used quetiapine for delirium in older patients and found that quetiapine is a safe and effective treatment in elderly patients with delirium. In a study made by Maneeton et al. (16) the authors compared haloperidol and quetiapine for treating delirium and found that both drugs were equally effective and safe for controlling delirium.
In our patient we also can not disconnected the patient from mechanical ventilator due to the delirium and anxiety. We firstly used haloperidol in our patient, but when we could not get enough response, we started quetipine by stopping haloperidol in the same doses as Devlin and Maneeton study.

In the same guidelines (14) it is suggested to avoid the routine use of haloperidol and antipsychotic agents such as quetiapine. In our patient we firstly used haloperidol after trying all treatment options and because of insufficient response quetiapine was started. It is not known enough to explain the efficacy of quetiapine in this delirium patient. However, quetiapine has been found to control agitation and lead to a significant improvement in cognitive abilities in this patient.

Second generation antipsychotic medications should be used with caution, especially in elderly patients due to cardiac side effects especially QTc prolongation (20). Sue et al. (20) made a study to access the effects of quetiapine on QTc prolongation, reported clinically insignificant change in the QTc following after quetiapine administration in critically ill patients and recommended electrocardiogram monitorization. Our patient was 33 years old but we checked the elektrocardiogram and measure the QTc in every day.

In conclusion, we suggest that second-generation antipsychotics should be kept in mind in patients who cannot be disconnected from the mechanical ventilator due to delirium.

\section{Ethics}

Informed Consent: Patient consent is obtained.

Peer-review: Externally and internally peer-reviewed.

\section{Authorship Contributions}

Concept: M.T.I., D.M., E.T.D., A.Ş.U., I.A., P.B., Design: M.T.I., D.M., E.T.D., A.Ş.U., I.A., P.B., Data Collection or Processing: M.T.I., D.M., E.T.D., A.S..U., I.A., P.B., Analysis or Interpretation: M.T.I., D.M., E.T.D., A.S..U., I.A., P.B., Literature Search: M.T.I., D.M., E.T.D., A.S..U., I.A., P.B., Writing: M.T.I., D.M., E.T.D., A.S..U., I.A., P.B.

Conflict of Interest: No conflict of interest was declared by the authors.

Financial Disclosure: The authors declared that this study received no financial support. 


\section{References}

1. Ely EW, Baker AM, Dunagan DP, Burke HL, Smith AC, Kelly PT, et al. Effect on the duration of mechanical ventilation of identifying patients capable of breathing spontaneously. N Engl J Med 1996;335:1864-9.

2. Esteban A, Anzueto A, Frutos F, Alía I, Brochard L, Stewart TE, et al. Characteristics and outcomes in adult patients receiving mechanical ventilation: a 28-day international study. JAMA 2002;287:345-55.

3. Sanders RD. Delirium, neurotransmission, and network connectivity: the search for a comprehensive pathogenic framework. Anesthesiology 2013;118:494-6.

4. Ouimet $S$, Kavanagh BP, Gottfried SB, Skrobik Y. Incidence, risk factors and consequences of ICU delirium. Intensive Care Medicine 2007;33:66-73.

5. Shehabi Y, Riker RR, Bokesch PM, Wisemandle W, Shintani $A$, Ely EW, et al. Delirium duration and mortality in lightly sedated,mechanically ventilated intensive care patients. Crit Care Med 2010;38:2311-8

6. Palencia Herrejon E. Diagnosis of delirium in the critical ill. Medicina Intensiva 2010;34:1-3.

7. Slutsky AS, Tremblay LN. Multiple system organ failure. Is mechanical ventilation a contributing factor? Am J Resp Crit Care Med 1998;157:1721-5.

8. Rosenthal LJ, Kim V, Kim DR. Weaning from prolonged mechanical ventilation using an antipsychotic agent in a patient with acute stress disorder. Crit Care Med 2007;35:2417-9.

9. Navalesi P, Frigerio P, Patzlaff A, Häußermann S, Henseke P, Kubitschek M. Prolonged weaning: from the intensive care unit to home. Rev Port Pneumol 2014;20:264-72.

10. Dellinger RP. Weaning from mechanical ventilation. In: Vincent JL, editor. Year book of Intensive Care and emergency medicine 1st ed. Heidelberg, CN: Springer-Verlag Berlin; 2006. p. 477-85.

11. American Psychiatric Association. Diagnostic and Statistical Manual of Mental Disorders. 4th ed. Washington DC: John Wiley \& Sons; 2000.

12. Trzepacz PT. Is there a final common neural pathway in delirium? focus on acetylcholine and dopamine. Semin Clin Neuropsychiatry 2000;5:132-48.

13. Al-Samarrai S, Dunn I, Newmark T, Gupta S. Quetiapine for treatment-resistant delirium. Psychosomatics 2003;44:350-1.

14. Devlin JW, Skrobik Y, Gelinas C, Needham DM, Slooter AJC, Pandharipande PP, et al. Clinical Practice Guidelines for the Prevention and Management of Pain, Agitation/Sedation, Delirium, Immobility, and Sleep Disruption in Adult Patients in the ICU. Crit Care Med 2018;46:825-73.

15. Swan JT, Fitousis K, Hall JB, Todd SR, Turner KL. Antipsychotic use and diagnosis of delirium in the intensive care unit. Crit Care 2012; 16:R84.

16. Maneeton B, Maneeton N, Srisurapanont M, Chittawatanarat K. Quetiapine versus haloperidol in the treatment of delirium: a doubleblind, randomized, controlled trial. Drug Des Devel Ther 2013;7:65767.

17. Devlin JW, Roberts RJ, Fong JJ, Skrobik Y, Riker RR, Hill NS, et al. Efficacy and safety of quetiapine in critically ill patients with delirium: A prospective, multicenter, randomized, double-blind, placebo-controlled pilot study. Crit Care Med 2010;38:419-27.

18. Seemüller F, Volkmer E, Vogel T, Hummel T, Krauseneck T, Riedel M, et al. Quetiapine as Treatment for Delirium During Weaning From Ventilation: A Case Report J Clin Psychopharmacol 2007;27:526-8.

19. Kim KY, Bader GM, Kotlyar V, Gropper D. Treatment of delirium in older adults with quetiapine. J Geriatr Psychiatry Neurol 2003;16:2931.

20. Sue L, Amanda M, Sarah K, Fanny L, Laura B. Impact of Quetiapine Therapy on QTc Prolongation in Critically III Patients. Annals of Pharmacotherapy 2019;53:705-10. 